\title{
Kentlerin Siyasi Fonksiyonları ve Türkiye Gerçeği
}

\section{Polat Tunçer ${ }^{1}$}

\section{Özet}

$\mathrm{Bu}$ çalışmanın amacı; uygarlığın beşiği olan kentlerin siyasi fonksiyonlarını, Türkiye bağlamında ortaya koymaktır. Konu, daha önce yapılan çalışmalar ışığında, teorik bir çerçevede ele alınmıştır. Kentler siyasi çalışmaların merkezi olarak, demokratik değerlerin yerleşmesine de öncülük etmiştir. Kentleşme ekonomik, sosyal, kültürel ve siyasi dönüşümleri içeren bir süreç olup, toplumsal değişme sürecini de önemli ölçüde etkileyen bir olgudur. Siyasi çalışmaların ve gelişmelerin merkezi haline gelen kentler, ulusal siyaseti derinden etkilemiştir. Kentler aynı zamanda demokratikleşme kültürünün kazanıldığı alanlardır. Küreselleşmeyle birlikte yerel yönetimler önem kazanmış, dolayısıyla kentlerin siyasi fonksiyonları da çeşitlenmiş ve artmıştır. Türkiye'de kentleşme; ekonomik, teknolojik, siyasal, sosyal ve kültürel gelişmelere paralel olarak, 1980'den sonra hılanmış; 2000'li yıllara gelindiğinde, nüfusun üçte ikisi kentlerde yaşamaya başlamıştır. Özellikle büyük kentlerde kapitalizmin gelişmesine bağlı olarak, geleneksel bağlar daha da sağlamlaşmış ve bireyler özgürleşmek yerine etnik ve dinsel kaynaklı cemaatlere yönelmiştir. Geleneksel siyasî yapı, kurum ve ilişkiler kentlerde de sürmüş; kent yönetimleri, önemli kaynakları kontrol eden, kullanan ve dağıtan bir görünüm kazanmıştır. Türkiye'de siyasi iktidara sahip olan partiler, genellikle kent yönetimlerine de sahip olduklarından, bu durum kent yönetimini merkezi idarenin siyasi etkisine açık hale getirmiş; kent yönetimi ile merkezi yönetim arasındaki ilişkilerde "partizanca" yaklaşımlara yol açmıştır. Bu tür davranışlar kentlerdeki siyasi yapılanma, çalışma ve tavırları etkilemiştir. Kent yönetimi ile merkezi yönetim arasındaki çeşitli yönlerden yaşanan çekişme ve çatışmalar, özerk ve demokratik kent yönetimi tartışmalarını da beraberinde getirmiştir. Kısaca kent kültürü siyasi davranışları değiştirirken, kentleşme siyasi çalışmaların yoğunlaşmasına ve demokratik değerlerin yerleşmesine yol açmıştır.

Anahtar kelimeler: Kent, Kentleşme, Kentlerin Siyasi Fonksiyonları, Kentsel Yönetişim, Yerel Yönetimler.

\footnotetext{
${ }^{1}$ Öğr.Gör.Dr., Ondokuz Mayıs Üniversitesi, Samsun Meslek Yüksekokulu e-mail: poltuncer@gmail.com
} 


\title{
The Political Functions of the Cities and the Turkey Reality
}

\begin{abstract}
The aim of the study is to reveal in the context of Turkey the political functions of cities which is the cradle of civilization. Subject is discussed in a theoretical framework in the light of previous studies. The cities pioneered to the establishment of democratic values as the center of political activities. The urbanization, significantly affected in the process of social change as a process economic, social, cultural and political covering transformation. The cities which has become the center of political studies and developments, deeply influenced national politics. The cities are areas which being acquired of democratization culture at the same time.The local governments have gained importance with globalization, therefore, diversified and increased also the political functions of cities. Accelerated urbanization in Turkey after 1980, with the effect of economic and technological developments, in the 2000s, started living in cities two-thirds of the population. Especially in large cities, depending on the development of capitalism, further consolidated its traditional ties and individuals directed towards ethnic and religious communities, instead of getting free. Social modernization, while the political modernization must give birth, İt has continued consolidating of the traditional political structures, institutions and relations. City governments have gained a view which uses significant resources, controls and distributes. The parties have the political power in Turkey, usually is having in the management of the city. This case, the city administration makes clear the political influence of the central administration and İt leads to partisan approaches in relations between central government and city management. This behavior is influenced in the cities on the political structures and attitudes. The struggles and conflicts which is taking place in various ways between city government and central government, also raises the debate over autonomous and democratic urban management. In short, while the urban culture change the political behaviors, the urbanization has led to the establishment of democratic values and the concentration of political studies.
\end{abstract}

Key words: Urban, Urbanization, Political Functions of Cities, Urban Governance, Local Government.

\section{GİRIŞ}

Uygarlığın beşiği olan kentlerin siyasi fonksiyonlarını Türkiye bağlamında ortaya koymak bu çalışmanın temel amacı olup, konu daha önce yapılan çalışmalar 1şı̆̆ında teorik bir çerçevede ele alınmıştır. Son yıllarda demokratikleşme eğilimlerinin artmasıyla birlikte kent yönetiminin de önemi 
artmış; dolayısıyla kentlerin siyasi fonksiyonları da bu bağlamda önem kazanmıştır.

Kentlerde yaşayanların talepleri teknolojik gelişmelerin meydana getirdiği değişimle birlikte artarak çeşitlenmeye başlamıştır. Demokratikleşme ile birlikte kent yönetimine katılmak ve kentsel sorunların çözümüne katkıda bulunmak isteyen vatandaşların ya da sivil toplum örgütlerinin faaliyetleri kentsel siyaseti daha da hareketlendirmiştir.

Küreselleşmeyle birlikte yerelleşme de önem kazanmış ve kent yönetiminin önemi artmıştır. Kent yönetiminin seçimi sırasında yaşanan siyasi olaylar ve siyasi gelişmeler kentin siyasi fonksiyonunu artırmıştır. Kentsel sorunlara en iyi çözümü kentte yaşayanların üreteceği yaklaşımı, kentsel siyaseti daha da önemli hale getirmiştir.

Bir taraftan ekonomik bağımsızlığı kazanmak ve gittikçe çeşitlenerek ağırlaşan görevlerini yapmak için gerekli olan, idari karar alma ve uygulama yetkisini, merkezi hükümetten bağımsız hareket edebilme gücünü, elde etmeye çalışan kent yönetimi, elindeki yetkileri de tarafsız ve etkin bir şekilde kullanamamaktadır. Bu bağlamda, kent yönetimin yönetişim sürecine geçmesi ve demokratikleşmesi oldukça yavaştır.

Özetle kentler siyasi faaliyetlerin sürekli ve yoğun yaşandığı alanlardır. Buradaki siyasi gelişmeler ve faaliyetler merkezi idarenin siyaseti üzerinde de etkili olmaktadır. Hatta iktidara talip olan partilerin kent yönetimindeki siyasi başarıları, onlara genel seçimlerde psikolojik destek sağlamaktadır. Kentlerdeki siyasi süreci iyi yönetmek, ülke yönetimi için referans teşkil etmektedir.

\section{A. Kentleşme Kavramı}

Siyasi açıdan kentler, belirli idari sınırlar içerisinde görev yapan yönetimlere sahip birimlerdir (İsbir, 1991: 5). Bir yerin kent olarak tanımlanabilmesi için dört kriter vardır; iktisadi, siyasi, demografik ve sosyolojik kriterler. Bu kriterlere göre kent; nüfusu belirli bir büyüklüğü ve yoğunluğu aşan, ekonomisi daha çok tarım dışı etkinliklerden oluşan ve kendi nüfusundan başka, etki alanı içinde yaşayanlara da hizmet sağlayan yerleşim yerleridir (Şahin, 2010: 5).

Sanayileşmeye ve ekonomik gelişmeye paralel olarak kent sayısının artması ve bugünkü kentlerin büyümesi sonucunu doğuran, toplumun yapısında, artan oranda örgütlenme, iş bölümü ve uzlaşma yaratan, İnsan davranış ve ilişkilerinde kentlere özgü değişikliklere yol açan, bir nüfus birikim süreci olarak da tanımlanabilir (Keleş, 2002: 22). 
Kentleşme, toplumsal değişme sürecini önemli ölçüde etkileyen ve bazı toplumlarda da hızlandıran bir olgudur. Başka bir deyişle, kentleşme yalnızca bir sonuç olarak kalmamakta, kentleşme göreli olarak yüksek bir hıza ve dereceye ulaştıktan sonra, ülkenin ekonomik, sosyal ve siyasi yapısını değişmeye zorlayan temel öğelerden biri olmaktadır (Kartal, 1978: 4-5). Uygarlık tarihinin ortaya çıkardığı bir olgu olarak kent, sosyoekonomik ve siyasi iktidar, mücadelelerinin yaşandığı mekândır. Kentlerin ortaya çıkma, gelişme ve değişme süreci "Kentleşme" kavramı ile ifade edilir. Evrensel bir olgu olan kentleşme, toplumların, siyasi ekonomik ve toplumsal yapısındaki, değişmelerin hem ürünü hem de belirleyicisidir (Tosun ve Tosun, 1995: 45).

Kent yönetimi, yerel hizmeti üreten ya da ürettiren idare sistemi olmasının yanı sıra, demokratik, kendi kendini yönetmeyi gerçekleştiren bir politik sistemdir. Bireyin günlük yaşamını yakından ilgilendiren kararların alınmasında ve uygulamasında etkinliğini gösterebileceği, bilgi, deneyim ve yeteneklerini harekete geçirebileceği alan kent yönetimidir (Cumhurbaşkanlığ DDK Yay., 1996: 2-3).

\section{B. Kentleşme Nedenleri}

Kentlerde yaşayan insan sayısının artmasına, kentteki hakim üretim tarzının tarımdan sanayi ve hizmet sektörüne kaymasına, kentte yaşayanların farklı bir kültürü benimsemelerine ve hepsinden önemlisi de kentteki farklılıkların hoşgörüyle karşılandığı bir iklimin oluşmasına etki eden faktörlerin tümüne birden kentleşme nedenleri denilmektedir (Şahin, 2010: 49). Kentler birçok bakımdan çekim merkezleridir. Kültürel değerler, iş, eğitim ve sağlık imkânları ile güvenlik kentleşmeye etki eden faktörler arasında sayılabilir (Kongar, 1999: 553-554). Genel olarak kentleşme nedenleri; ekonomik, teknolojik, siyasal ve sosyo-psikolojik nedenler şeklinde sayılabilir (Keleş, 2002: 26). Kentleşmenin nedenlerini; itici, iletici, çekici ve siyasal nedenler şeklinde de sınıflandırmak mümkündür (Kartal, 1978: 6-8):

- İtici Nedenler: Tarıma yeni teknolojinin girişi, toprak yetersizliği ve toprakların mirasla parçalanması, entansif tarıma (makineleşme olmadan emeğin açığa çıkması) geçiş, nüfusun artışı ve yaşam biçiminin kısırlığı gibi nedenlerdir.

- İletici Nedenler: Haberleşme ve ulaşım imkânlarının gelişmesi, ulaşım ve iletişim teknolojilerindeki gelişmeler, mal ve hizmet üretiminin ve dağıtımının belli merkezlerde toplanması. 
- Çekici Nedenler: İş imkânları sağlayan sanayi ve hizmet kuruluşları, genellikle kentlerde ya da onların çevresinde kurulmaktadır. Kent geliri göreli olarak köydekine göre yüksektir. Kent yaşamının canlılığı ve kentte eğitim, eğlence gibi imkânların göreli üstünlüğü ve fazlalığı.

- Siyasi Nedenler: Çeşitli düzeylerde verilen kararlar, yönetim yapısının özelliği, uluslararası ilişkiler gibi nedenler sayılabilir.

\section{Kentin Siyasi Fonksiyonları}

Kentlerin fonksiyonları çok çeşitli olmakla birlikte; ekonomik, kültürel, idari ve siyasi fonksiyonlar olmak üzere üç grupta toplanabilir (İsbir, 1991: 9). Günümüzde hızlı kentleşme ve demokratikleşme eğilimleri, kenti siyasal erk paylaşımı için yapılan çalışmaların önemli odaklarından biri haline getirmiştir (Ökmen, 2008: 5).

Siyasi hayat açısından, kentleşmenin ortaya çıkardığı, en önemli olgu; toplumsal hareketlilik ve bunun siyasete etkileridir. Toplumsal hareketlilik yaklaşımına göre, sosyo-ekonomik ve demografik değişmeler siyasi yapı ve davranışları biçimlendirir. Modernleşmeci teorilere göre, kente göçen kitlelerin, siyasi deneyim ve katılımları artacak ve siyasi sistemden talepleri yükselecek, siyasi ve toplumsal kurumlar da demokratikleşme yönünde gelişecektir. Ancak, çeşitli ülke deneyimleri, siyasi modernleşmenin pozitivist bakış açısının her zaman gerçekleşmediğini göstermektedir (Tosun ve Tosun, 1995: 47-49).

Bireyler daha iyi yaşam şartlarına kavuştukça politikadan uzaklaşmaktadır (Öner, 1998: 91-93). Kentin özellikle varoşlarında yaşayan yoksulların siyasi ve toplumsal sistemle entegre olmamalarının yarattığı yabanc1laşma, modernleşmeci teorilerin öngördüğü istikrar ve dengenin aksine, istikrarsızlığa, radikalizme ve siyasi çatışmanın yaşanmasına ortam hazırlayabilir. Kentlere göç edip de, kentle bütünleşememiş insanların neden sosyal patlamalara yol açmadığı göreli refah kavramıyla açıklanmaktadır. Kentleşme sürecinde, siyasi yapılanmayı etkileyen olgulardan birisi de, kırdan göç edenlerin, kırsal yaşam tarzını ve toplumsal ilişkiler sistemini olduğu gibi kente taşımalarıdır (Tosun ve Tosun, 1995: 50-52).

İnsanlar kentleri üzerinde karar verme yetkisini ne merkezi iktidara ne giderek onun bir uzantısı haline gelen yerel yönetimlere ne de kent konusunda evrensel bir bilimselliğin taşıyıcısı olduğunu iddia eden uzmanlara bırakmalıdır. Asıl inisiyatif kentlilerin yüzlerce konuda oluşturacakları örgütlere geçmelidir. Kentlilerin etkin katılımı olmadan, onlar için iyi bir kent kurulamaz (Bumin, 
2010: 4). Toplumsal değişkenler siyasal katılma biçimlerini etkilemektedir. Kişilerin siyasal katılma düzeylerini, bireysel özellikleri yanı sıra ekonomik, toplumsal ve kültürel değişkenler de etkilemektedir. Kimi değişkenler siyasal katılmayı hızlandırmakta kimileri ise yavaşlatmakta hatta engellemektedir (Özer, 2004: 89).

Rousseau, doğrudan demokrasinin uygulanabileceği toplumu eşitsizliğin olmadığ1 ve bir kent devleti büyüklüğünü aşmayan bir toplum olarak tanımlamaktadır. Doğrudan demokrasi kentsel düzeyde uygulanabilecek önemli bir araç olarak görülmektedir. Doğrudan demokrasi, halka, kentsel bazı önemli konularda daha etkin olarak karar almasına yardımcı olacak seçenekler sunma anlamını taşımaktadır (Çukurçayır, 2006: 151-152). Doğrudan demokraside halk kentsel sorunlara aktif olarak çözüm üretir ve yaşam çevresinin biçimlendirilmesi sürecine etkili olarak katılır. Bu bağlamda, teknolojik gelişmeler doğrudan demokrasinin uygulanmasına olumlu katkıda bulunmaktadır. Ancak bu imkânların yeterince kullanılması ve katılımcılığın yaygınlaştırılması, kent yöneticilerinin anlayışlarıyla doğru orantılıdır.

Kentlinin öncelikle kent yaşamına, devamında kentin yönetimine aktif ve etkin biçimde katılmaları, gerekli katılımcı demokrasi kültürünün yerel ölçekte oluşturulması ile gerçekleştirilir (Parlak, 2008: 69). Değişen ve gelişen yeni kamu yönetimi anlayışı çerçevesinde alınacak kararlara vatandaş katılımının azami düzeyde sağlanması gerekmektedir. Aksi takdirde kent yönetiminin özerkliğinden beklenen yararlar gerçekleştirilemez.

Yönetim anlayışının değişmesiyle birlikte, merkezi idareye ait birtakım yetkilerin kent yönetimlerine devredilmesi, kentsel siyasetin önemini ve sorumluluğunu artıracaktır. (Çukurçayır, 2006: 106). Kent yönetiminin özerkliği, onun hem merkezi idare hem de halkla olan ilişkilerinin boyutunu değiştirecektir (Bulut, 1996: 175). Özgürce karar alma ve uygulama gücüne sahip kentlerde siyasi çalışmalar yoğunlaşacaktır.

Çağımızdaki hızlı kentleşme ve demokratikleşme, kentleri siyasal gücün paylaşımı için yapılan mücadelelerin merkezi haline getirmiştir. Kentsel siyasetin dar ve geniş olmak üzere iki anlamı vardır: Dar anlamdaki kentsel siyasette; yerel düzeyde karar alma süreçlerini etkileyen tüm etmenlerin incelenmesi gerekir. Geniş anlamda ise kentleşme sürecini ve yerel birimleri ilgilendiren bütün etkinlikler ve politikalar kentsel siyaset kapsamına girer. Kent siyaseti kavramının içeriği şöyle sıralanabilir (Keleş, 2000: 101):

- Kirsal ve kentsel alanlarla ilgili konular, 
- Yerel yönetimlerle devlet arasındaki ilişkiler,

- Yerel seçimler,

- Siyasi erki eline geçirmek isteyen güçlerin, yerel düzeydeki güç odaklarıyla devlet arasındaki çelişkiler ve çevre duyarlılığı.

Siyasetle kentin tarihsel bağları vardır. Birçok düşünür, kenti uygarlığın ve demokrasinin beşiği olarak görmektedir. Siyasi erk gücünü hangi kaynaktan alırsa alsın, siyasal erkin güçlenmesi ve yayılması kentlerin varlığını ve gelişmesini gerekli kılmıştır (Keleş, 2000. 102).

Kentsel hareketler, Batı'da, özellikle altmışlı yıllardan itibaren geleneksel politik (seçim) ve sendikal mücadelelerin yanı sıra gelişerek geniş kitlelerin bilinçlenmesi için çok önemli bir aracı, doğrudan demokrasinin, katılımcı demokrasinin okulu olma yoluna girmiştir (Bumin, 2010: 158). Yerel düzeyde vatandaşın siyaset aktörleriyle yüz yüze etkileşiminin daha kolay ve yaygın olması, nüfusun göreceli homojenliği ve yerel sorunların da topluluğun çoğu için aynı anlamı taşıması, yerel siyaset açısından katılımcı bir yapılanmayı kolaylaştırıcı etkenlerdir (Çukurçayır, 2006: 121). Demokratik değerlerin yaygınlaşmaya başlaması bu süreci desteklemekte ve iletişim teknolojilerindeki gelişmeler kentsel siyasetin boyutunu değiştirmektedir.

İletişim teknolojileri yönetime katılmayı ya da kent yöneticilerinin vatandaşların istek ve taleplerini öğrenmelerini kolaylaştırmıştır. Yönetim anlayışındaki değişimle birlikte kavramlar da değişmeye başlamış; geleneksel kamu örgütlerindeki idare (administration) ile özel sektördeki yönetim kavramının (management) yerini yönetişim (govarnance), kavramı almıştır (Genç, 2005: 15). Hem yönetim hem de politikayla ilgili olan bu süreç, toplumla etkileşim halinde gerçekleştirilir. Bürokratik düzenlemelerin radikal biçimde kaldırılması ve yüksek derecede katılımın sağlanmasıyla büyük ölçüde desantralize olan sosyal sistem içinde kamu yönetimi amaçlarını gerçekleştirmek mümkün olacaktır (Corrigan and Joyce, 1997: 422). Yönetişim yaklaşımının en iyi uygulanabileceği alan kent yönetimidir. Kent sakinlerince oluşturulan sivil toplum örgütleri vasıtasıyla kentsel sorunların çözümü daha demokratik ve katılımcı bir biçimde gerçekleştirilebilir.

Kamuda yönetişim, yönetim ve karar alma süreçlerinin tüm paydaşlarının işbirliği ve katılımı ile yapılmakta olduğunu, yöneticilerin uzlaşmacı, saydam, hesap verebilir, etkin ve sorumlu bir yönetim anlayışı içinde davrandıklarını anlatır. Bir başka deyişle, yönetim sadece seçilenler tarafından 
değil, sivil toplum kuruluşları, odalar, meslek kuruluşları, özel sektör kuruluşları, üniversiteler gibi çeşitli grupların da sürece katılmaları gerekir (Toksöz, 2008: 17). Yönetişim, demokrasinin prensiplerine ve insan haklarına sadakattir. Yönetişim demokrasinin kuvvetlenmesini, temel insan haklarını ve katılımcı yönetimi gerektirir. İyi yönetişim için, halkın sesini yerel, bölgesel ve ulusal seviyede duyurmas1 gerekir. $\mathrm{Bu}$ da ancak demokratik kurumlar vasitasıyla gerçekleşir (Bayraktar vd., 2003: 202-203).

Çağdaş gelişmeler neticesinde kent yönetiminden, kentsel yönetişime geçilmiştir. Kentsel yönetişim, yerel demokrasinin sağlanması, hizmet kalitesinin gerçekleştirilmesi ve yerel sorunların çözümünde, yerel ölçekte bilgi ve kapasitenin kullanımını gerektirmektedir. $\mathrm{Bu}$ noktada kentsel yönetişimin başlıca sorunu, yurttaşların çözüme ortak olma anlamında, sosyal birikimin yeterince güçlendirilmesi gereğidir. Aksi takdirde yerel yönetişim çalışmaları sosyal, ekonomik ve siyasi çözümler üretmeyen retorik çabaları olarak kalacaktır (Palabıyık, 2003: 254-255).

İdari ve siyasi fonksiyonları bulunan kentler vatandaşlar için bir çekim merkezidir. Kentlerin sahip oldukları siyasi fonksiyonlar, ülkeler arasında da farklılık gösterir. Merkeziyetçi yönetim şeklinin benimsendiği ülkelerin başkentleri bütün siyasi faaliyetlerin merkezidir. Hâlbuki federal devletlerdeki başkentlerde aynı siyasi yoğunluk görülmez. Devlet bürokrasisinin ihtiyaç duyduğu personelin başkentlere yerleşmesi yanında çeşitli iş ve hizmet imkânından yararlanmak isteyenlerin kısa süreli ziyaretleri bu kentlerdeki nüfus yoğunluğunu artıran en önemli faktördür. Bu tür bir siyasi fonksiyona sahip kentler süratle gelişerek metropol kentlere dönüşürler (İsbir, 1991: 11).

Yerel halkın yaşadıkları kentlerdeki siyasi etkinliklerini artırma konusunda AB önemli çalışmalar yapmış ve kararlar almıştır. Bunlardan birincisi 7 Şubat 1992'de Maastricht'te Avrupa Birliği Antlaşması'yla ortaya çıkmıştır. Bu konuyla ilgili diğer önemli belge de, Avrupa Konseyi, Avrupa Yerel ve Bölgesel Yönetimler Konferansı'nca 18 Mart 1992'de kabul edilen Avrupa Kentsel Şartı'dır. Şarta göre; Avrupa yerleşimlerinde yaşayan kent sakinleri, güvenlik, kirletilmemiş sağlıklı bir çevre, istihdam, konut, dolaşım, sağlık, spor ve dinlence, kültür, kültürler arası dayanışma, kaliteli bir mimari ve fiziksel çevre, katılım, ekonomik kalkınma, sürdürülebilir kalkınma, doğal zenginlikler ve kaynaklar, kişisel bütünlük, belediyeler arası işbirliği, eşitlik başlıklarıyla ele alınan haklara sahiptir. Yine şarta göre, kentsel gelişmenin 
temelini, özerk ve mali bağımsızlığg olan yerel yönetimlerde, halkın doğrudan kentsel kararlara katılımının sağlanması oluşturur (Ökmen, 2003: 49-50).

\section{Türkiye'de Kent ve Siyaset}

Türkiye'deki kentleşme olgusu ülkenin toplumsal ve ekonomik yapısını biçimlendiren temel öğelerden biridir. Ülkenin kentleşme süreci 1980'den sonra hızlanmıştır. 2000'li yıllara gelindiğinde Türkiye nüfusunun üçte ikisi kentlerde yaşamaktadır. Kente göç edenlerin büyük çoğunluğunu 15-24 yaş grubu oluşturur. Ancak göç etme eylemi aile çapında gerçekleştirilmektedir (Kongar, 1999: 549-550).

10.000'den fazla nüfuslu yerlere kent adı verilirse, Türkiye'nin kentleşme düzeyinin 1997 'de $\% 64.6,2000$ y1lında \%65.01 olduğu görülür. Kentlerimizde yaşayan nüfus 44 milyon civarındadır. Kent tanımında nüfus ölçütü yerine yönetsel statü ölçütü kullanılır; il ve ilçe merkezlerinde yaşayan nüfusa kentsel nüfus denilirse, bu durumda kentsel nüfus \%65'i geçmektedir. 1960-2000 yılları arasındaki 40 yıllık sürede kentsel nüfus, 6.9 milyondan 44 milyona çıkarak 6 kat artmıştır. Aynı dönemde kent sayısı da 147'den 470 çıkmıştır (Keleş, 2002: 57-59).

Bugün Türkiye'de kent yönetimlerinin yeniden düzenlenmesi başlıklı tartışmaların hepsinin amacı, kent yönetimlerini verimli hizmet üreten, demokratik, birer kurum haline getirmektir. Üniter bir devlet yapısı içinde reformist bir anlayışla yapılmak istenen idari yerinden yönetim anlayışından siyasi yerinden yönetim uygulamasına geçmektir (Bulut, 1996: 179).

İkinci Dünya Savaşı'nın ardından hızlanan kentleşme, başta gecekondulaşma ve çevre kirliliği olmak üzere kentsel sorunları çeşitlendirmiş ve artırmıştır. $\mathrm{Bu}$ sorunlar uzun yıllar merkezi idare tarafından merkezden çözülmeye çalışılmış ve kent yönetimine gerekli olan yetki, sorumluluk ve kaynak verilmemiştir. Bu durum ise sorunların daha da artmasına ve içinden çıkılmaz bir hal almasına neden olmuştur. Sonunda; demokratikleşme, insan hakları ve hukuk devleti alanlarında meydana gelen gelişmelerin yanı sıra, yeni kamu yönetimi anlayışının da etkisiyle, kentsel sorunların çözümü için kent yönetimine yetki verilmesi ve kaynak aktarılması gündeme gelmiştir. Ancak yine de kent yönetimlerinin kentsel sorunların çözümüyle ilgili gerekli ve yeterli yetkilerle donatıldığı söylenemez. Bununla birlikte eskiye nazaran bu konuda önemli gelişmeler yaşanmış olup, bu durum kentsel siyaseti hareketlendirmiş ve etkinliğini artırmıştır. 
Kentlerde seçilmek için politikayla uğraşan kişilerin sayısı az olmakla birlikte şu veya bu şekilde politik bir çalışmanın içinde yer alan insanların sayısı oldukça fazladır (Daşöz, 1995: 181-182). Kent hizmetlerinin mali yükünü taşıyan halk, mali kaynakların hangi alanlara ve hangi usullerle kanalize edildiğinin hesabını sorabilmeli, yönetim üzerinde ağırlığını sürekli hissettirebilmelidir (Cumhurbaşkanlığı DDK Yay., 1996: 63). Kent sakinleri yaptığı tercihin dikkate alındığını ve kendisinin karar alma sürecinde etkili olduğunu görürse, kentteki siyasi davranışlarını artırmaya ve geliştirmeye gayret sarf eder. Aksi taktirde siyasete ve siyasetçilere duyduğu güvensizlik demokratik katılıma dair isteksizlik uyandırır.

Kentleşme ile siyasi katılmanın yalnız düzeylerinde değil, şekil ve temellerinde de önemli değişmeler olduğu gözlenmektedir. Küçük yerleşim birimlerinde siyasi ilişkiler ve siyasi yapı karmaşılıktan uzaktır. Öte yandan çok nüfuslu büyük metropollerde siyasi yapı karmaşıtır. Buralarda karmaşık bir süreç sonunda alınan siyasi kararları birey etkileyememektedir. İletişim kolaylığı, merkeze yakınlık ve sosyal etkileşim gibi imkânların kentlerde bulunması siyasi katılımı artırmaktadır. Kentleşme aynı zamanda siyasi katılmayı teşvik edici nitelik taşımaktadır (Öner, 1998: 81-84).

Son dönemlerde kent yönetimleri, özellikle de Büyükşehir yönetimleri önemli kaynakları kullanan ve kentin rantlarını kontrol eden ve dağıtan bir görünüm kazanmışlardır. Türkiye'de siyasi iktidara sahip olan partiler, genellikle kent yönetimlerine de sahip olmaktadır. Bu durum kent yönetimini merkezi idarenin siyasi etkisine açık hale getirmekte kent yönetimi ile merkezi yönetim arasındaki ilişkilerde "partizanca" yaklaşımlara neden olmaktadır (Öner, 1997: 215-216).

Siyasi olayların açılanmasında kentleşme özel bir öneme sahiptir. Kent hayatı; bir yandan oy verme, bürokratlarla yazışma, seçim kampanyalarına katılma ve toplumsal normlara uygun eylemlerde bulunma gibi olağan siyasi katılmaya, etkilerde bulunurken diğer yandan da olağandışı siyasi katılmayı besleyen şartları, oluşturmaktadır (Bulut, 1996: 172).

Yerel yönetimler, kentte yaşayan halka en yakın yönetimler olmaları bakımından yerel ortak ihtiyaçları en iyi şekilde tespit ederek optimal hizmet üretimini sağladıkları savunulmaktadır. Yerel yönetimlere verilen yetki ve sorumlulukların artışına paralel olarak vatandaşların siyasi bilinçleri ve sorumluluk duyguları da artmakta ve gelişmektedir (Çoker, 1995: 95). Artık yerel siyaset ve ulusal siyaset ayrımı söz konusu değildir. Yerel seçimlerde oy 
verme davranış1, büyük ölçüde ulusal siyasi sorunlar tarafından belirlenmektedir. Yerel seçimlerde oy verme davranışı büyük ölçüde parti etiketine bağlı olarak gerçekleşmektedir (Çitci, 1989: 13).

Ülkenin hızlı kentleşmesi, kent ve anakent sayısının artması, büyüyen kentlerin halkının her türlü ihtiyaçlarını yeterince karşılayabilmek için, milli gelirden hakça pay alma girişimleri kent yönetimini giderek siyasallaştırmakta, siyasi partiler arasında pazarlık konusu yapılmaktadır (Keleş, 1995: 66). Kent yönetimlerinin siyasileşmesi ve merkezi yönetimin politik etkisine açık olması, merkezi yönetimin de önemli bir sorunu olan "siyasi ve idari yozlaşmayı" da beraberinde getirmektedir (Öner, 1997: 217).

Kentleşme ile siyasi katılımın arttı̆̆ yönündeki iddialar Türkiye açısından geçerli değildir. Kentleşme sonucu kente gelen kitlelerin kullandıkları oyların yönünde değişme meydana gelmektedir. Genellikle kalabalık nüfuslu yerlerde seçmen oyları daha çok değişim yanlısı; az nüfuslu yerlerde ise tutucu eğilimler görülmektedir. Kentleşmenin toplum içinde yarattığı yeni bölünmelerin toplumsal çatışmayı artıracağı, özellikle kente göç eden kitlelerin siyasi patlamaya neden olacağı, bilhassa kentin yoksul göçmenlerinin devrimci bir niteliğe sahip olacakları iddiası ile kente göçenlerin kentte kalış süresi arttıkça soldaki partilere oy verme oranının arttı̆gı; düşük ve orta gelir gruplarının sol partilere oy verme oranlarının yüksek, yüksek gelir düzeyindekilerin bu partilere oy verme oranlarının da düşük olduğu (Öner, 1998: 89-90) iddiası da Türkiye gerçeği ile uyuşmamaktadır. Bu bağlamda kentin siyasi fonksiyonlarıyla ilgili pek çok veri Türkiye'nin kendine has siyasi yapılanması ve gerçekleriyle paralellik taşımamaktadır. Yönetimde durumsallık yaklaşımı burada da geçerlidir denilebilir.

Kırsal değerlerle kentsel değerler arasında sıkışıp kalmış kitlelerin kentle, bütünleşememelerinin temelinde yaşadıkları kimlik sorunu yatmaktadır. Gerek aşırı sol, gerekse aşırı sağ örgütlerin, ocaklar, hücreler, tarikatlar aracılığıla sunduğu ve bunlara çekici gelen olgu; kimliktir. 70'li yıllardaki kentleşme hareketine bağlı olarak, Türkiye'nin siyasi yapılanma sürecinde, iktidarda ya da muhalefette olsun, tüm partilerin patronaj ilişkileri devam etmektedir. 1950'lerdeki ilişkiler daha çok aile ve hemşehrilik ilişkilerine dayanırken, 1970'lerde geleneksel ilişkilerin yerini, siyasî ilişkiler almıştır. 1980'lerden günümüze, Türkiye'de siyasi partiler, 1970'lerden daha yoğun biçimde siyasi iktidarın asıl belirleyicisinin büyük kentler olduğunun farkına varınca alınan tüm siyasi kararlarda öncelikle bu kentlerde yaşayanların 
isteklerine cevap vermek düşüncesi hakim olmuştur. Kentteki kamu hizmetlerinin yetersizliği ve kente göçenlerin köydeki sosyal ilişkilerini ve davranışlarını sürdürme eğiliminde olmaları, kitlelerin yoğunlaşan taleplerinin acilen karşılanmasını gerektirmektedir. Kente göçen bireyler, yabancılaşma, korku ve endişelerinden kurtulmak için bir otorite arayışına girmekte; buna da cemaatler, sivil toplum örgütleri ve yasa dışı örgütler aracılığıyla ulaşmak istemektedirler (Tosun ve Tosun, 1995: 57-60).

Toplumsal modernleşmenin, siyasi modernleşmeyi doğurmas1 gerekirken, geleneksel siyasi yapıların, kurumların ve ilişkilerin pekişerek devam ettiği görülmektedir. Özellikle yerel politikanın yapılma sürecini önemli ölçüde etkileyen kentle ilgili rantların dağıtımı, genel anlamda siyasi yozlaşmanın da yaygın bir görüntüsüdür. Bu yozlaşmanın ortaya çıkmasında kamu yönetiminin yerel yönetimleri taşradaki uzantısı gibi gören tipik merkeziyetçi bakış açısının etkisi büyüktür (Tosun ve Tosun, 1995: 61-63).

Dünyanın birçok ülkesinde ve bu arada ülkemizde, toplumun değişik kesimlerinde ve değişik siyasi anlayışlar arasında, yerel yönetimlerin güçlendirilmesi ve geliştirilmesi konusunda ortak bir anlayış doğmuştur. Kent yönetimlerinin güçlendirilmesi, yerel yönetimlere özerklik verilmesi ve bu yönetimler üzerindeki merkezi denetimin en aza indirilmesi konularında çoğu ülkelerde başlayan gelişmeler, uluslararası belgelerde ve ülkelerin anayasalarında daha açık bir biçimde yer almaya başlamıştır. Bu bağlamda, demokrasinin güçlendirilmesi ve yaygınlaştırılması konusunda kent yönetimlerine daha çok görev düşmektedir. Yerel yönetimler bu süreçte, yalnızca etkin ve verimli hizmet sunan birimler olarak değil, aynı zamanda demokratik siyasi kurumlar olarak yeni işlevler üstelenmektedir (Ökmen, 2005: 540).

\section{SONUÇ}

Sanayi devrimiyle birlikte kentleşme hızlanmış; kentlileşen yeni kitlelerin talepleri artmış ve kentsel sorunlar çeşitlenmiştir. Kentleşme sürecinde ortaya çıkan talep ve ihtiyaçları karşılamak, kentleşmenin oluşturduğu sorunları çözmek; önceleri ağırlıklı olarak, merkezi idarenin sorumluluğu altındayken, teknolojik, ekonomik, sosyal ve kültürel gelişmeler neticesinde ortaya çıkan yeni kamu yönetimi anlayışı ile birlikte bu hizmet ve sorunlar yerinde görülmeye ve çözülmeye başlamıştır. $\mathrm{Bu}$ bağlamda dünyada artan demokratikleşme eğilimleri yerel yönetimlerin önemini artmıştır. $\mathrm{Bu}$ durum ise 
kentlerdeki siyasetin hareketlenmesine ve yoğunlaşmasına yol açmıştır. Böylece kentsel siyasetin önemi ve etkinliği biraz daha artmış; katılımcı demokrasi güçlenmeye ve yaygınlaşmaya başlamıştır.

Kürselleşen dünyadaki yeni kamu yönetimi anlayışının ortaya çıkardığı katılımcı demokrasi, yerinden yönetim, şeffaflık, hesap verilebilirlik, insan hakları gibi temel değerler yanında $\mathrm{AB}$ 'nin yönetim alanındaki standartları da $\mathrm{AB}$ uyum sürecinde bulunan Türkiye'de yerel siyasetin önemini artırmıştır.

Türkiye'de kentleşme İkinci Dünya Savaşından sonra başlamıştır. Bilhassa çok partili hayata geçtikten sonra artan demokratikleşme ve tarımdaki makineleşmeyle birlikte başlayan kentlere göç hareketinde kırsal bölgelerdeki işsizlik de önemli bir rol oynamıştır. Hatta bu göç yalnızca yurt içindeki kentlerle sınırlı kalmamış, yurt dışına da (özellikle Almanya) işçi akınları biçiminde gerçekleşmiştir.

Kırsal alandan göçen ve kentin varoşlarında toplanan yığınların talepleri ve beklentileri demokratik yönetim sayesinde dikkate alınmaya başlamıştır. Bununla birlikte, uzun bir süre kentlerdeki siyaset kent sakinlerinin kısa dönemli çıkarlarına hitap eder hale gelmiştir. Kentin yönetimini ele geçirmek isteyen siyasi partiler, varoşlarda oturan ve henüz tam olarak kentlileşmemiş fakat kentin bütün imkânlarından yararlanmak isteyen kitlelerin beklentileri doğrultusunda siyasi vaatlerde bulunmuşlardır. Kimliğini, kişiliğini ve geleneklerini muhafaza etmek, kaybolmamak, ezilmemek ve yeni bir kimlik edinmek isteyen yarı kentli kitlelerin hemşehricilik duygusuyla birbirlerine destek olmaları ve çeşitli organizasyonlara katılmaları, siyasi çalışma ve gelişmelere yön vermiştir. Zamanla yerel ve ulusal siyaset üzerinde etkili olduklarını anlayan, varoşlarda yaşayan yarı kentlilerin siyasete olan ilgileri artmış; böylece kentsel siyaset çeşitlenmiş ve yoğunlaşmıştır.

Diğer faktörlerin yanı sıra katılımcı demokrasinin eksikliği kentsel siyasetin gelişmesini engellemiş ona olan ilgiyi azaltmıştır. Yerel hizmetlerle ilgili kararların merkezi idare tarafından alındığını bilen ve bürokratik vesayeti yaşayan kentli sakinler uzun yıllar yerel siyasete gereken ilgiyi göstermemişlerdir. Yerel hizmet ya da sorunlarla ilgili karar süreçlerinde etkin ve etkili olduklarını fark eden kentlilerin siyasi faaliyetleri artmıştır. İletişim ve ulaşım alanındaki gelişmeler kentsel siyaseti olumlu yönde etkileyerek siyasi bilinçlenmeyi sağlamıştır.

Türk siyasetinin en temel problemlerinden birisi olan aşırı merkeziyetçi yapı, günümüzde adem-i merkeziyetçi bir yapılanmaya doğru evrilmektedir. 
Demokratikleşmenin artmasıyla birlikte insan hak ve hürriyetlerinde yaşanan gelişmeler sayesinde, sivil siyasetin alanı da genişlemekte ve imkânları artmaktadır. Bu durum kentsel siyaseti pozitif yönde etkilemektedir. Değişen, gelişen, küreselleşen ve küçük bir köye dönüşen dünyamızda, kent yönetimi önem kazanmış ve ülke yönetimine devlet adamı yetiştiren siyasi kurumlar haline gelmiştir.

\section{KAYNAKLAR}

Bayraktar, K.; Altıöz, M.; Tutar, H. (2003); Kamu-Özel Kesim Yapısı ve İlişkileri, Ankara, Nobel Yay.

Bulut, Y. (1996); "Belediye Yönetiminin Yeniden Düzenlenmesinde Gündemden Düşmeyen Konular”, Türk İdare Dergisi, Y11 68, Say1 413, s.171-184.

Bumin, K. (2010); Demokrasi Arayışında Kent, 4. Baskı, Çizgi Kitabevi Yay. Corrigan, P.; Joyce, P. (1997); "Reconstructing Public Management: A New Responsibility fort he Public and a Case Study of Local Government", International Journal of Bublic Sector Management, Vol. 10, No. 6, p.417-432.

Cumhurbaşkanlığı Devlet Denetleme Kurulu Başkanlığ1 Yayını (1996); Yerel Yönetimler Sorunları- Çözüm Önerileri, Ankara.

Çitci, O. (1989); Yerel yönetimlerde Temsil, Ankara, TODAİE Yay.

Çoker, Z. (1995); Yönetimde Yeniden Yapılanma, Ankara, 20 Mayıs Eğitim, Kültür ve Sosyal Dayanışma Vakfı Yay.

Çukurçayır, M. A. (2006); Siyasal Katılma ve Yerel Demokrasi, 3. Bask1, Konya, Çizgi Kitabevi Yay.

Daşöz, H. İ. (1995); “Bask1 Altındaki Yerel İdareler”, Türk İdare Dergisi, Y1l 67, Say1 409, s.181-185.

Genç, N. (2005); Yönetim ve Organizasyon, 2. Bask1, Ankara, Seçkin Yay. İsbir, E. G. (1991); Şehirleşme ve Meseleleri, 2. Baskı, Ankara, Gazi Büro Yay. Kartal, K. (1978); Kentleşme ve İnsan, Ankara, TODAİE Yay.

Keleş, R. (2000); Yerinden Yönetim ve Siyaset, 4. Baskı, İstanbul, Cem Yay. Keleş, R. (2002); Kentleşme Politikası, 7. Baskı, Ankara, İmge Yay.

Keleş, R. (1995); "Yerel Demokrasinin Neresindeyiz?” Yeni Türkiye (Yönetimde Yapılanma Özel Sayıs1), Yı1 1, Sayı 4, s.66-71.

Kongar, E. (1999); 21. Yüzyılda Türkiye, 20. Bask1, İstanbul, Remzi Kitapevi Yay. 
Ökmen, M. (2003); “Globalleşme-Yerelleşme Dinamikleri ve Bir İnsan Hakk1 Olarak Yerel Haklar", Yerel ve Kentsel Politikalar, Ed. M. Akif Çukurçayır-Ayşe Tekel, Konya, Çizgi Kitabevi Yay., s.49-50.

Ökmen, M. (2005); "Küreselleşme Sürecinde Yerelleşme Eğilimleri ve Yerel Yönetimler”, Yerel Yönetimler Üzerine Güncel Yazılar - I, Ed. Hüseyin Özgür - Muhammet Kösecik, Ankara, Nobel Yay., s.539-564.

Ökmen, M. (2008); "Kentsel Alanda Aktörler Arası İşbirliği ve Kalkınma Çabaları: Salihli Örneği”, Değişen Kentler ve Değişen Yerel Yönetimler, Ed. Fatma Nevval Genç-Abdullah Yılmaz-Hüseyin Özgür, Ankara, Gazi Kitabevi Yay., s.3-25.

Öner, Ş. (1998); “Kentleşme ve Modernleşmenin Siyasal Davranışlar Üzerindeki Etkisi”, Türk İdare Dergisi, Y1l 70, Say1 420, s.65-96.

Öner, Ş. (1997); “Türkiye'de Merkezi Yönetim ile Belediyeler Arasındaki İlişkilerin Yasal-Siyasal ve Ekonomik Analizi”, Türk İdare Dergisi, Y1l 69, Say1 414, s.211-225.

Özer, İ. (2004); Kentleşme, Kentlileşme ve Kentsel Değiş̧me, Bursa, Ekin Yay. Palabıyık, H. (2003); "Yönetimden Yönetişime: Yönetişim, Kentsel Yönetişim ve Uygulamaları ile Yönetişimde Ölçülebilirlik Üzerine Açıklamalar", Yerel ve Kentsel Politikalar, Ed. M. Akif Çukurçayır - Ayşe Tekeli, Konya, Çizgi Kitabevi Yay., s.225-277.

Parlak, B. (2008); "Kent Kültürü ve Kentlilik Bilinci Geliştirme Projesi: Bursa Büyükşehir Örneği”, Dönüşen Kentler ve Değişen Yerel Yönetimler, Ed. Fatma Nevval Genç-Abdullah Yılmaz-Hüseyin Özgür, Ankara, Gazi Kitabevi Yay., s.61-85.

Şahin, Y. (2010); Kentleşme Politikası, Trabzon, Murathan Yay.

Toksöz, F. (2008); İyi Yönetişim El Kitabı, İstanbul, TESEV Yay.

Toksöz, F. (1995); "Yerel Yönetim Sistemine Eleştirel Bir Bakış: Yeni Bir Model Anlayışı", Yeni Türkiye (Yönetimde Yapılanma Özel Sayısı), Y11 1, Say1 4, s.352-360.

Tosun, G.; Tosun, T. (1995); “Türkiye'de Kentleşme Siyasal Yapılanma İlişkisi”, Amme İdare Dergisi, Cilt 28, Sayı 4, s.45-63. 